\title{
Repurposing of Chloroquine and Its Derivative, Hydroxychloroquine for COVID-19: Implications for People Living with HIV in
}

\section{Africa}

Chiagoziem Anariochi Otuechere

Department of Biochemistry, Faculty of Basic Medical Sciences, Redeemer's University, Ede, Osun State, Nigeria

Correspondence: Dr. Chiagoziem A. Otuechere; otuecherec@run.edu.ng; +234-8023887060

\begin{abstract}
The coronavirus disease 2019 (COVID-19), caused by the severe acute respiratory syndrome coronavirus 2, has been declared by the World Health Organization (WHO) as a pandemic. Unfortunately, finding a vaccine or developing drugs from the scratch is a timeconsuming luxury given the widespread and high fatality rates of the virus. In the short term, repurposing of drugs already in use seem to be the most rational step to quickly and effectively curb the virus. Several antiviral agents had been proposed as possible remedies, but the 4-aminoquinolines, Chloroquine (CHQ) and hydroxychloroquine (HCHQ) appear to be generating more interest. They are generic, cheaply available and have proven efficacy against malaria parasites in Africa. The human immunodeficiency virus (HIV), on the other hand, targets the immune system thereby reducing the patient's ability to fight infections. Sadly, $68 \%$ of the global HIV burden occur in Africa. It is therefore anticipated that incidence of severe forms of COVID-19 could occur in Africa because of associated endemic conditions that
\end{abstract}


compromise the immune system. With CHQ and HCHQ being considered for clinical use against COVID-19, there is a need to highlight their potential merits and confounding variables in the subgroup of patients with or without HIV.

KEYWORDS: coronavirus disease 2019; chloroquine; drug repurposing; HIV; Africa

\section{Introduction}

Early December 2019, several people residing in Wuhan, China, presented with symptoms including pneumonia, fever, and difficulties in breathing. These symptoms quickly spread in the community and by January 2020, the World Health Organization (WHO) had confirmed the $\beta$-coronaviruses as the causal organisms. The disease was later designated as coronavirus disease 2019 (COVID-19). By late January 2020, the WHO had described the disease as a pandemic because it had spread to a score of countries with thousands of confirmed cases, and over two hundred fatalities [1]. As of 31 March 2020, a total of 571659 cases of COVID-19 have been confirmed globally including 26493 mortalities. By 10 April 2020, these figures had escalated tremendously to over 1.56 million, including 95044 deaths. Surprisingly, the African region known for several pandemic outbreaks had a relatively lower number of confirmed cases (12280) and deaths (630) in comparison to Asia (260549 cases; 9831 deaths), America (537678 cases; 19309 deaths), and Europe (745262 cases; 65207 deaths) [2]. These data showed that the highly infectious nature of the disease. It also revealed that incidence of the virus in Africa was limited compared to Europe and North America. However, there are concerns that Africa lacks the requisite medical infrastructure to tackle the upsurge in cases. In addition, data on infected but asymptomatic persons is sparse. Culturally, Africans still adhere to some conservative beliefs, thereby raising concern of stigmatization that could deter infected individuals from seeking orthodox treatment. This could lead to under- 
reporting of cases in the continent and preclude effective surveillance and monitoring [3]. Evidence emanating from the demographics of patients infected with COVID-19 in Wuhan, China indicated that the elderly and patients with comorbid conditions such as hypertension, diabetes, cardiovascular disease, or chronic lung disease were at higher risks of severe outcomes, including death [4-5]. Presently, there is no data on the effect of COVID-19 infection on HIV immune-compromised patients, but it is reasonable to speculate that this sub-group may require special clinical care. As at the time of this report (10 April 2020) there was just a single study on a patient presenting with a co-infection of COVID-19 and HIV in Wuhan, China [6]. Contrariwise, HIV-infected patients receiving standard anti-HIV drugs might not have increased risk for COVID-19, as was the case in Thailand [7]. However, a nation-wide community survey of people living with HIV in China buttressed the need for HIV-specific protective measures during this outbreak [8]. The comprehensive case reports from other high incidence countries such as the USA, Italy and Spain are still being awaited. In the interim, severe pneumonia-like symptoms, caused by the Middle East Respiratory Syndrome Coronavirus (MERS CoV), were observed in a HIV patient [9]. (Shalhoub et al, 2015). To underscore the need for further evaluation of the association between HIV and COVID-19, a fatal case was reported in a patient presenting with influenza A H5N1 and HIV co-infection [10]. While the search for anti-COVID-19 drugs is ongoing, repurposing of drugs previously used to treat other diseases could be the best short-term solution. A set of guidelines released by the WHO, the Center for Disease Control and Prevention, and the United States Food and Drug Administration have proposed several potential drugs to treat COVID-19 infections. These drugs (with their mechanisms of action) included darunavir, lopinavir, ritonavir, imatinib (inhibit key enzymes involved in virus replication); interferon- $\alpha$ (blocks viral replication); ribavirin (blocks viral mRNA synthesis); remdesivir (inhibits RNAdependent RNA polymerases); azithromycin and tocilizumab (suppress cytokine production), CHQ and HCHQ (inhibit ACE 2 cellular 
receptors and viral DNA/RNA polymerases [11-12]. CHQ and HCHQ are cheaply available in Africa. The pharmacokinetic and pharmacodynamic profiles of CHQ had been studied extensively, including as an immuno-modulator during HIV infection [13]. This review discusses the anti-viral activities of CHQ and HCHQ and the variables of their use in the treatment of patients with COVID-19, with or without an underlying HIV infection.

\section{The evolvement of CHQ and HCHQ as anti-viral agents}

Chloroquine (CHQ), chemically designated as an N4-(7-Chloro-4-quinolinyl)-N1, N1-diethyl-1, 4-pentanediamine, had been in use as an antimalarial drug for several decades. Hydroxychloroquine (HCHQ), with similar pharmacokinetic profile as CHQ, has a $\beta$-hydroxyl group attached to the $\mathrm{N}$-di-ethyl substituent of CHQ leading to their slightly different clinical indications. The consideration of CHQ and HCHQ as antiviral agents against the coronavirus 2019 is an example of drug repurposing, a strategy that deploys already existing drugs for new medical indications. Up till the year 2000, CHQ remained the first-line therapy for uncomplicated malaria in sub-Saharan countries. Its use waned as a result of the development of resistance by Plasmodium falciparum strains. Incidentally, CHQ use in sub-Saharan Africa never abated as it had remained accessible to the general population [14-15].

Earlier studies indicated the inhibitory effect of CHQ on the growth of mouse hepatitis virus and other animal viruses such as polio type 1, influenza, Newcastle disease [16-17]. In a specific study, chick embryo cells were exposed to vesicular stomatitis virus and treated with CHQ $(12.5 \mu \mathrm{g} / \mathrm{ml})$, resulting in depleted viral yield [17]. In the past three decades, Africa had been plagued by Lassa fever, Ebola virus, Marburg virus, Rift Valley fever, and the Crimean-Congo hemorrhagic virus (CCHFV) [18]. In the course of the CCHFV epidemic in Africa, researchers proposed the repurposing of CHQ to treat the virus. In a study utilizing Vero E6 and Huh 7 cell lines, the 50\% inhibitory 
concentration values for CHQ against two different CCHFV strains ranged from 28 to $43 \mu \mathrm{M}$. Several combinations, including CHQ and ribavirin, also showed synergistic effect against CCHFV [19]. The use of CHQ as an anti-viral agent gained prominence against the Ebola virus, a filovirus that had proved to be re-emerging in sub-Saharan Africa [20]. In an in vitro study in MRC-5 human cell lines, CHQ at the concentrations of 4.7 and $0.47 \mu \mathrm{M}$, significantly reduced the cycle threshold of viral RNA levels following post-infection with the Ebola virus. The anti-viral effects of CHQ were linked to its ability to limit the acidification of the endosomes [21]. In yet another study, MT-4 cells infected with X4, R5 or R5/X4 HIV-1 strains from clades A-E and HIV-2 were treated with CHQ concentrations ranging from $0-12.5 \mu \mathrm{M}$. Results showed that CHQ, at the tested concentrations, blocked the HIV-1 post-integration by affecting newly produced viral envelope glycoproteins [22]. Similar successes had been achieved using CHQ against Chikungunya infection in Vero E6 cells. Consistent with the results obtained with MT-4 cells infected with the Ebola virus, the preponderant mechanism of the anti-viral action of CHQ in Vero E6 cells infected with the Chikungunya virus was the modification of the endosomal pH [23]. An earlier review had hypothesized that CHQ could exert direct antiviral effect against coronaviruses by inhibiting their $\mathrm{pH}$-dependent replications [24]. A study demonstrating the inhibitory effect of CHQ against the replication of human coronaviruses strain OC43 corroborated this hypothesis [25]. These workers reported that $\mathrm{CHQ}$ inhibited $\mathrm{HCoV}-\mathrm{OC} 43$ replication in HRT-18 cells, with a 50\% effective concentration of $0.306 \mu \mathrm{M}$. In a more recent study, CHQ and HCHQ inhibited SARS-CoV-2 infected Vero cells with 50\% effective concentrations of 5.47 and $0.72 \mu \mathrm{M}$, respectively [26]. Despite its potential, the deployment of CHQ as a treatment strategy for viral infections has been dampened by several in vivo studies indicating a lack of protection. At a dose of $33.75 \mathrm{mg} / \mathrm{kg}$, CHQ administered per os for 8 days, afforded no protection in guinea pigs exposed to the Ebola virus [21]. This is in agreement with another study that showed that the therapeutic intervention with CHQ resulted 
in toxicity and did not extend the survival of rodents infected with the Ebola virus [27). In clinical trials, the shadow of doubt on the efficacy of CHQ as an antiviral molecule had persisted. In a randomized control trial, 54 patients infected with the Chikungunya virus received 600 mg of CHQ per day for three days and an additional dose of $300 \mathrm{mg}$ for another two days. Results revealed that CHQ treatment did not affect viremia or clinical parameters during the acute stage of the disease [23]. Following the outbreak of COVID-19 in December 2019, anecdotal reports of the antiviral efficacy of CHQ and HCHQ resurfaced. In the face of the global pandemic, the first documented clinical trial of CHQ in COVID-19 infected patients was quickly conducted in China. In a multi-center clinical trial involving over 100 patients, CHQ inhibited COVID-19 associated pneumonia and also improved clearance of virus from the lungs [28]. Another early clinical study, a single-arm protocol human study, was conducted with HCHQ in France. Findings from this study revealed that HCHQ alone and in combination with azithromycin was highly effective in clearing viral nasopharyngeal carriage within six days in COVID-19 subjects [29]. Although these two clinical studies used small sample sizes and not-too-robust protocols, they served as baseline for other studies. For example, the synergistic effect on viremia observed with the combination therapy of HCHQ with azithromycin could be the basis for an ongoing clinical trial in China using CHQ and favipiravir. Currently, there are ongoing clinical intervention studies in several countries testing the efficacy of CHQ and HCHQ as drug candidates against COVID-19 infection. A simple search in two registries, the US-based clinical trials.gov and the Chinese Clinical Trial Register using keywords such as COVID-19, Coronavirus, (Hydroxy) Chloroquine yielded over twenty-three entries from fifteen different countries (Table 1).

TABLE 1: Ongoing clinical trials on Chloroquine and Hydroxychloroquine for COVID-19 infection 


\begin{tabular}{|c|c|c|c|c|c|c|}
\hline Study ID & $\begin{array}{l}\text { Treatment } \\
\text { Indication }\end{array}$ & $\begin{array}{l}\text { Study Design and } \\
\text { number of recruits }\end{array}$ & $\begin{array}{l}\text { Date of } \\
\text { Registration }\end{array}$ & $\begin{array}{l}\text { Country of } \\
\text { study }\end{array}$ & $\begin{array}{l}\text { Phase and } \\
\text { Status of } \\
\text { Study }\end{array}$ & Study Objective \\
\hline NCT04333732 & $\begin{array}{l}\text { COVID-19: } \\
\text { Healthcare } \\
\text { Workers at } \\
\text { Risk }\end{array}$ & M-RCT, n=55000 & April 2020 & $\begin{array}{l}\text { US, Canada, } \\
\text { Australia, UK, } \\
\text { South Africa, } \\
\text { Ireland }\end{array}$ & $\begin{array}{l}\text { Phase 2; Not } \\
\text { yet Recruiting }\end{array}$ & $\begin{array}{l}\text { To protect healthcare workers by } \\
\text { administering } \mathrm{H}(\mathrm{CHQ}) \text { as a strategy to } \\
\text { prevent collapse of healthcare services }\end{array}$ \\
\hline NCT04333628 & $\begin{array}{l}\text { COVID 19: } \\
\text { Mild } \\
\text { Symptomatic } \\
\text { and } \\
\text { Asymptomati } \\
\text { c patients }\end{array}$ & M-RCT, n=210 & April 2020 & Israel & $\begin{array}{l}\text { Phase 2; Not } \\
\text { yet Recruiting }\end{array}$ & $\begin{array}{l}\text { To test whether a low dose CHQ will } \\
\text { reduce the duration of the viral shedding } \\
\text { and disease worsening }\end{array}$ \\
\hline NCT04333914 & $\begin{array}{l}\text { COVID-19 } \\
\text { infection and } \\
\text { cancer }\end{array}$ & M-RCT, n=273 & April 2020 & China & $\begin{array}{l}\text { Phase 2; Not } \\
\text { yet Recruiting }\end{array}$ & $\begin{array}{l}\text { To compare the combined efficacy of a } \\
\text { CHQ analog (GNS561) + Nivolumab + } \\
\text { Tocilizumab in patients with cancer and } \\
\text { COVID } 19 \text { Infection }\end{array}$ \\
\hline
\end{tabular}




\begin{tabular}{|c|c|c|c|c|c|c|}
\hline NCT04330144 & $\begin{array}{l}\text { COVID-19: } \\
\text { Contact of a } \\
\text { COVID-19 } \\
\text { confirmed } \\
\text { patient }\end{array}$ & M-RCT, n=2486 & April 2020 & South Korea & $\begin{array}{l}\text { Phase } 3 \text {; Not } \\
\text { yet Recruiting }\end{array}$ & $\begin{array}{l}\text { To evaluate the efficacy and safety of } \\
\text { HCHQ as post exposure prophylaxis for } \\
\text { COVID- } 19\end{array}$ \\
\hline NCT04331600 & $\begin{array}{l}\text { COVID-19: } \\
\text { Ambulatory } \\
\text { patients and } \\
\text { those with co- } \\
\text { morbid } \\
\text { conditions }\end{array}$ & M-RCT, $n=400$ & April 2020 & Poland & $\begin{array}{l}\text { Phase } 4 \text {; Not } \\
\text { yet Recruiting }\end{array}$ & $\begin{array}{l}\text { To evaluate the efficacy of CHQ in } \\
\text { combination with telemedicine for } \\
\text { COVID-19 }\end{array}$ \\
\hline NCT04322396 & $\begin{array}{l}\text { COVID-19 } \\
\text { Infection }\end{array}$ & M-RCT, $n=226$ & March 2020 & Denmark & $\begin{array}{l}\text { Phase } 4 \text {; Not } \\
\text { yet Recruiting }\end{array}$ & $\begin{array}{l}\text { To explore whether the combined HCHQ } \\
+ \text { Azithromycin treatment could reduce } \\
\text { hospitalization stays of COVID infected } \\
\text { patients. }\end{array}$ \\
\hline NCT04303507 & $\begin{array}{l}\text { COVID-19: } \\
\text { Acute } \\
\text { Respiratory } \\
\text { Illness }\end{array}$ & M-PT, $n=40000$ & March 2020 & Several & $\begin{array}{l}\text { Phase } 0 \text {; Not } \\
\text { yet Recruiting }\end{array}$ & $\begin{array}{l}\text { Prevention of COVID-19 in the } \\
\text { Healthcare Setting }\end{array}$ \\
\hline NCT04328493 & $\begin{array}{l}\text { COVID- } \\
19 \text { :Infection }\end{array}$ & $\mathrm{M}-\mathrm{RCT}, \mathrm{n}=250$ & March 2020 & Vietnam & $\begin{array}{l}\text { Phase } 0 \text {; Not } \\
\text { yet Recruiting }\end{array}$ & $\begin{array}{l}\text { To evaluate potential therapeutics for the } \\
\text { treatment of hospitalized COVID- } 19 \\
\text { patients }\end{array}$ \\
\hline NCT04324463 & $\begin{array}{l}\text { COVID 19: } \\
\text { Clinical } \\
\text { Progression of } \\
\text { infection }\end{array}$ & M-RCT, n=1500 & March 2020 & Canada & $\begin{array}{l}\text { Phase } 3 \text {; Not } \\
\text { yet Recruiting }\end{array}$ & $\begin{array}{l}\text { To evaluate the potential of CHQ } \\
+ \text { Azithromycin as therapies to reduce the } \\
\text { clinical progression of COVID } 19 \text {. }\end{array}$ \\
\hline NCT04323527 & $\begin{array}{l}\text { COVID-19: } \\
\text { Treatment of } \\
\text { Hospitalized } \\
\text { Patients With }\end{array}$ & S-RCT, $n=400$ & March 2020 & Brazil & $\begin{array}{l}\text { Phase 2; } \\
\text { Recruiting }\end{array}$ & $\begin{array}{l}\text { To assess whether the use of CHQ reduces } \\
\text { mortality by } 50 \% \text { in the study population } \\
\text { of hospitalized patients }\end{array}$ \\
\hline
\end{tabular}

Severe Acute 
Respiratory

Syndrome

NCT04321278

COVID-19:

Pneumonia

COVID-

19 :Infection

COVID-19:

Pneumonia

COVID-19:

Pneumonia

COVID-19:

Pneumonia

COVID-19:

mild clinical

symptoms

Fever,

respiratory

symptoms

\section{COVID-19:}

Pneumonia

and other

severe

symptoms

COVID-19:

Pneumonia
M-RCT, $\mathrm{n}=440 \quad$ March $2020 \quad$ Brazil

M-RCT, n=1300 March $2020 \quad$ France

M-RCT, $n=150$

March 2020

China

S-RCT, $n=80$

March 2020

China

S-SA, $n=100$

Feb 2020

China

M-PGS, $\mathrm{n}^{1}=50 ; \quad$ Feb 2020

China

$\mathrm{n}^{2}=50$

M-PGS, $\mathrm{n}^{1}=50 ; \quad$ Feb 2020

China

$\mathrm{n}^{2}=50$

M-RCT, n=180 Feb 2020

China
Phase 3;

Recruiting

Phase 3; Not

Yet Recruiting

Phase 2-3;

Recruiting

Phase 4;

Recruiting

Phase 0;

Recruiting

Phase 4;

Recruiting

Phase 4;

Recruiting

Phase 4;

Pending

Approval
To compare the efficacy of HCHQ + Azithromycin combination therapy with that of HCHQ alone in adult patients hospitalized with pneumonia caused by COVID-19

To study the improvement prognosis and reduction in the risk of death in COVID-19 patients treated with HCHQ To evaluate the efficacy and safety of combined therapy of CHQ + Favipiravir against COVID-19

Evaluation the efficacy and safety of CHQ against COVID-19

To investigate the clinical effect of $\mathrm{CHQ}$ on COVID-19

To explore the comparative efficacy and safety of CHQ and HCHQ in patients with mild and respiratory symptoms of COVID-19

To explore the comparative efficacy and safety of CHQ and HCHQ in patients with pneumonia and other severe symptoms of CIVID-19

To investigate the efficacy of HCHQ against pneumonia in COVID-19 


\begin{tabular}{|c|c|c|c|c|c|c|}
\hline ChiCTR2000029803 & $\begin{array}{l}\text { COVID-19: } \\
\text { Confirmed } \\
\text { cases }\end{array}$ & $\begin{array}{l}\text { S-PCS, } n^{1}=80 \\
n^{2}=80\end{array}$ & Feb 2020 & China & $\begin{array}{l}\text { Phase } 0 \text {; Not yet } \\
\text { Recruiting }\end{array}$ & $\begin{array}{l}\text { To evaluate the preventive effect of HCHQ } \\
\text { on close contacts of confirmed COVID-19 } \\
\text { patients }\end{array}$ \\
\hline ChiCTR2000029975 & $\begin{array}{l}\text { COVID-19: } \\
\text { Pneumonia }\end{array}$ & $\mathrm{S}-\mathrm{SA}, \mathrm{n}=10$ & Feb 2020 & China & $\begin{array}{l}\text { Phase } 4 \text {; Not yet } \\
\text { Recruiting }\end{array}$ & $\begin{array}{l}\text { To explore use of CHQ aerosol inhalation for } \\
\text { COVID-19 }\end{array}$ \\
\hline ChiCTR2000029542 & $\begin{array}{l}\text { COVID-19: } \\
\text { Pneumonia }\end{array}$ & S-PCS, $n=20$ & Feb 2020 & China & $\begin{array}{l}\text { Phase } 4 \\
\text { Recruiting }\end{array}$ & $\begin{array}{l}\text { To evaluate the safety of CHQ in } \\
\text { hospitalized patients with COVID-19 }\end{array}$ \\
\hline ChiCTR2000029559 & $\begin{array}{l}\text { COVID-19: } \\
\text { Pneumonia }\end{array}$ & $\mathrm{S}-\mathrm{SA}, \mathrm{n}=300$ & Feb 2020 & China & $\begin{array}{l}\text { Phase } 4 \\
\text { Recruiting }\end{array}$ & To evaluated the HCHQ against COVID-19 \\
\hline
\end{tabular}

Last search was run on 04 April 2020 using https://clinicaltrials.gov and http://www.chictr.org.cn. The key search words were COVID-19, Coronavirus, Chloroquine (CHQ) and Hydroxychloroquine (HCHQ), H (CHQ) = Chloroquine and Hydroxychloroquine; BID = twice daily; ? = not indicated. $\mathrm{n}=$ number of recruits; S-SA= Single center Single Arm Study; SCPCS= Single Centre Prospective Cohort Study; S-RCT=Single Centre Randomized Controlled Trial; M-PCS=Multicenter Prospective Cohort Study; M-RCT= Multicenter Randomized Controlled Trial; M-PT= Multicenter Prophylaxis Trial; M-PGS= multicenter parallel group study.; i.v. = intravenous. Route of administration is oral except indicated

These trials, conducted in single or multi-centers, varied in their design, dosing, duration, and route of drug administration. Several studies in the registries had been canceled and some duplication was also observed across the two registries. A search on Pan African Clinical Trials Registry (npactr.samrc.ac.za) using the same keywords did not reveal any ongoing clinical trial in sub-Saharan Africa. However, on 18 March 2020, the WHO announced a global SOLIDARITY Trial involving the study of remdesivir, CHQ, lopinavir/ritonavir, and lopinavir/ritonavir plus interferon- $\beta$. As of 3 April 2020, only South Africa had formally joined the programme. Moreover, the Nigerian National Agency for Food and Drug Administration and Control recently announced the commencement of mass manufacture of CHQ for emergency distribution and clinical treatment of COVID-19. Hopefully results from these studies would provide ample evidence on the efficacy of the 4-aminoquinolines and other drugs as pharmacological agents against the coronavirus 2019. 


\section{COVID-I9 proteins as therapeutic targets for CHQ and HCHQ}

The synthesis of proteins and their maturation are necessary for the replication of viruses. These steps could be targeted in the development of antiviral agents [30]. Viral proteins could be classified as structural, nonstructural, regulatory or accessory. Anti-HIV drugs targeting many of the HIV viral proteins and enzymes had been produced. Drugs blocking the reverse transcriptase (Zidovudine, Stavudine, Nevirapine, Etravirine), protease (Saquinavir, Ritonavir, Darunavir) or the integrase (Raltegravir, Dolutegravir) had led to a significant increase in life expectancy of people living with HIV in Africa [31-32].

As of 6 March 2020, a landmark breakthrough was achieved with a report of the first whole genomic sequencing of COVID-19 in Africa. This research was conducted at the African Centre of Excellence for the Genomics of Infectious Disease (ACEGID), Redeemer's University, Ede, Nigeria in collaboration with the Nigerian Institute of Medical Research [33]. Interestingly, the length of this fully sequenced genome was 29759 bp, comparable with that of SARS-COV $(\approx 29700$ bp) [34]. The experience gained from elucidating the mechanisms of action of anti-HIV drugs targeting viral enzymes could prove invaluable in unraveling potential targets to suppress the replication of COVID-19.

The enzymatic machinery in the COVID-19 genome is powered by the proteases (3-chymotrypsin-like and papain-like proteases), helicase, and RNA-dependent RNA polymerase, while the enzymes found in HIV-1 included protease, reverse transcriptase and integrase [35-37].

Other structural and accessory proteins of COVID-19 and HIV-1 are summarized in Table 2.

TABLE 2: Comparison of viral proteins in COVID-19 and HIV-1

\begin{tabular}{|c|c|c|c|c|}
\hline \multirow[b]{2}{*}{ Nature of protein } & \multicolumn{2}{|c|}{ COVID-19 } & \multicolumn{2}{|c|}{ HIV-1 } \\
\hline & Name of protein & Key role of protein & $\begin{array}{l}\text { Name of protein } \\
\text { (encoding gene) }\end{array}$ & Key role of protein \\
\hline
\end{tabular}




\section{Structural}

Spike glycoprotein or S protein

Involved in the attachment of the virus to the host cell receptors; also facilitates viral entry into the host cell

Membrane protein

Nucleocaspid protein

Envelope protein
Involved in the viral assembly

Plays a role in viral assembly and budding

Involved in viral assembly and budding
Matrix protein (Gag)

Caspid protein (Gag)

Nucleocapsid (Gag)

Nucleic acid-stabilizing protein $(\mathrm{Gag})$

Surface protein or gp 120 (env)

Transmembrane protein or gp

41 (env)
Involvement in viral assembly and facilitation of infection of non-dividing cells

Forms the core of virus particles. Also important for viral infectivity and uncoating

Serves to coat the RNA genome inside the virion and protects against the action of nucleases

Incorporates the virus protein $r$ during viral assembly

Binds to specific cell surface receptors to facilitate viral entry Mediates fusion between viral cellular membranes after receptor binding 


\section{Enzymes}

Papain-like proteases

Chymotrypsin-like proteases

RNA-dependent RNA polymerase

Helicase

Open reading frame $3 b$ protein

Open reading frame 6 protein

\section{Catalyzes the replication of RNA from an RNA template}

Cleavage of viral polypeptide chain at specific peptide bonds

Cleavage of viral polypeptide chain at specific peptide bonds

Unwinding of double stranded nucleic acids

Subverts innate host response by inhibiting interferon synthesis and signaling

Subverts innate host response by inhibiting interferon synthesis and signaling
HIV-1 protease (Pol)

Reverse transcriptase (Pol)

Integrase (Pol)

Viral protein $r$

Virion infectivity factor

Viral protein $\mathrm{u}$
Proteolytic cleavage of group specific antigen proteins; release of structural proteins and viral enzymes

Transcription of viral genome into double stranded DNA. Acts as catalysts for RNAdependent and DNAdependent DNA polymerization reactions

Catalyzes reactions that integrate the viral genome into a host chromosome

Facilitates virus infectivity

Production of infectious virus in vivo

Modulates intracellular trafficking 
Transactivator of transcription
$\begin{aligned} & \text { Regulator of virion protein } \\ & \text { expression }\end{aligned}$

Negative regulatory factor
Activates viral gene transcription

Controls export of nonspliced and partially spliced viral mRNA

Necessary for HIV replication and pathogenesis

Gag= Group-specific antigen; env= Envelope protein; pol= polymerase; $g p=$ Envelope glycoprotein

Several excellent reports have emerged on the therapeutic potentials of CHQ and HCHQ against the coronavirus. Various mechanisms had been put forward to explain the anti-viral activity of CHQ against COVID 19 [24, 26, 37, 38]. Some of these mechanisms included: inhibition of glycosylation at the virus receptor ACE 2, stabilization of lysosomal membranes, inhibition of new virus particle transport, immunomodulation of cytokines, and inhibition of viral polymerases. CHQ had been reported to reduce viral infectivity in HIV-1 experimental models without interfering with the HIV enzymes, reverse transcriptase, and integrase. This lack of interference had prompted the testing of CHQ and HCHQ in combination with antiretrovirals in clinical intervention studies [39]. It is reasonable to speculate that the mechanisms of action of CHQ and HCHQ in HIV could give an insight into their therapeutic activities in enveloped viruses. Taken together, targeting the enzymatic machinery of the COVID-19 could be exploited in the development of adjunctive therapy 
against the disease. Presently, different combination strategies are being adopted to elicit better and sustained viral response against COVID-19 infection. Clinical trials using the following combinations are currently ongoing: CHQ and Tocilizumab (China); CHQ and Favipiravir (China) and H (CHQ) and Azithromycin (Brazil, Canada, Denmark). The growing popularity of Azithromycin as an adjuvant to CHQ and HCHQ in the treatment of COVID-19 could be as a result of their lack of inhibition of the cytochrome P450 superfamily responsible for the metabolism of the 4-aminoquinolines. Consequently, deleterious drug-drug interactions are not envisaged (Tables 3).

TABLE 3: Potential drug-drug interactions of Chloroquine and Hydroxychloroquine with other experimental COVID-19 drugs

\begin{tabular}{|c|c|c|}
\hline Drug & Indication & Interactions with Chloroquine and Hydroxychloroquine \\
\hline Atazanavir & $\begin{array}{l}\text { HIV-1 infection; Protease } \\
\text { inhibitor }\end{array}$ & $\begin{array}{l}\text { Atazanavir is an inhibitor of CYP3A4, a member of the Cytochrome P450 superfamily that } \\
\text { mediates }(\mathrm{H}) \text { CHQ metabolism. Co-administration increases plasma concentration of }(\mathrm{H}) \\
\text { CHQ. The weak basicity of } \mathrm{H}(\mathrm{CHQ}) \text { also affects the solubility of Atazanavir. Dose } \\
\text { adjustment and clinical monitoring may be required. }\end{array}$ \\
\hline Lopinavir/ritonavir & $\begin{array}{l}\text { HIV-1 infection; Protease } \\
\text { inhibitor }\end{array}$ & $\begin{array}{l}\text { Lopinavir and ritonavir are inhibitors of CYP3A, a member of the Cytochrome P450 } \\
\text { superfamily that mediates CHQ metabolism. Co-administration increases plasma } \\
\text { concentration of } \mathrm{CHQ} \text {. Dose adjustment and clinical monitoring may be required. }\end{array}$ \\
\hline Remdesivir & $\begin{array}{l}\text { Tested against Ebola virus; } \\
\text { inhibitor of RNA-dependent } \\
\text { RNA polymerases }\end{array}$ & $\begin{array}{l}\text { Remdesivir is an inhibitor of CYP3A4, a member of Cytochrome P450 superfamily that } \\
\text { mediates CHQ metabolism. However, its potential for drug-drug interaction with either } \\
\text { CHQ or HCHQ is minimal because of favourable pharmacokinetic properties of rapid } \\
\text { distribution, metabolism and clearance. }\end{array}$ \\
\hline
\end{tabular}


Favipiravir

Ribavirin

Tocilizumab

Azithromycin

interferon-beta
Developed for influenza virus; inhibitor of RNA-dependent

RNA polymerases

Used against respiratory

syncitial virus and some viral

hemorrhagic fevers; blocks viral

mRNA synthesis

A therapy for rheumatoid

arthritis; Anti-inflammatory

agent that blocks Interleukin-6

expression

An antibacterial drug used to treat respiratory, ocular, retinal, and sexually transmitted infections A cytokine used to treat multiple sclerosis; Shows antiviral effect by blocking the replication of viruses
Favipiravir is a weak inhibitor of CYPs 2D6 and 3A4 member s of the Cytochromes P450 superfamily that mediates $(\mathrm{H}) \mathrm{CHQ}$ metabolism. Based on Favipiravir biotransformation and excretion profiles, adverse drug-drug interactions with either CHQ or HCHQ are reduced. Dose adjustment and clinical monitoring may be required.

There is no report on ribavirin inhibition of Cyt P45 enzymes; hence there is little or no drug-drug interaction with either $\mathrm{CHQ}$ or $\mathrm{HCHQ}$. Dose adjustment and clinical monitoring may be required.

Tocilizumab has no direct inhibitory effect on CYP3A4 necessary for H (CHQ) metabolism. However, in the presence of inflammatory conditions, Tocilizumab down regulates interleukin 6 expression which is accompanied by restoration of CYP 3A4 to normal levels. Although no significant adverse effects was observed in combination with either CHQ or HCHQ, dose adjustments and close monitoring of patients may be required. Azithromycin does not inhibit cytochrome P450 enzymes. There are no current in vivo or clinical studies reporting any adverse drug-drug interactions with H(CHQ). However dose adjustment may be required in patients being treated with Azithromycin in combination with either CHQ or HCHQ.

Interferon-beta does not inhibit cytochrome P450 enzymes. There are no animal or clinical studies reporting adverse drug-drug interactions with $\mathrm{H}$ (CHQ). However dose adjustment may be required in patients being treated with Azithromycin in combination with either CHQ or HCHQ. 
$\mathrm{CHQ}=$ Chloroquine; $\mathrm{HCHQ}=$ Hydroxychloroquine; $\mathrm{H}(\mathrm{CHQ})=$ Chloroquine and Hydroxychloroquine; $\mathrm{CYP}=\mathrm{Cytochrome}$

\section{Repurposing CHQ and HCHQ as antiviral drugs: knotty issues in the African setting}

Despite several studies describing the molecular mechanisms of the anti-viral effects of CHQ and HCHQ, a number of issues remain unsolved. One major factor is the paucity of safety data on CHQ and HCHQ, obtained from human studies over a period of time. The majority of the studies addressing the antiviral effects of the 4-aminoquinolines had relied on in vitro studies that were unable to fully capture their biological responses in human disease conditions. Hence, the therapeutic utility of CHQ and HCHQ, and their appropriate clinical doses, in the treatment of COVID-19 needs to be established from the ongoing clinical trials. This will also put to rest the discordant tunes emanating from different regulatory bodies and medical associations. An editorial published in The BMJ on 8 April 2020 cautioned against the use of CHQ and HCHQ for the treatment of COVID-19 because the antimalarial drugs were effective in laboratory experiments but lacked robust data from clinical settings [40]. A news release also reported the cancellation of trials involving CHQ as an anti-COVID19 drug. Patients had complained of severe headaches, loss of vision and cramps [41]. In the not too distant future, the University of Oxford-anchored Randomised Evaluation of COVID-19 Therapy (Recovery Trial) using HCHQ, and other ongoing studies across the globe, would provide better and properly powered clinical trials that would determine the fate of CHQ and HCHQ as therapeutic interventions against COVID-19. In Africa, where CHQ presents a cheap option to treat the coronavirus 2019, its potential to cause adverse effects in people living with other underlying medical conditions is a source of worry. For example, people with HIV, who are already on lopinavir and ritonavir therapy, might suffer toxicity when exposed to CHQ and HCHQ. Lopinavir and ritonavir are inhibitors of CYP3A, a member of the Cytochrome P450 superfamily that mediates CHQ metabolism. Co-administration of these antiretroviral drugs with CHQ 
increases the plasma concentration of CHQ due to inhibition of the drug-metabolizing machinery of cytochrome P450. Cardiac arrhythmias are major public health issues in sub-Saharan Africa [42], but drugs such as Amiodarone, Bepridil and Flecainide, used to manage these conditions, are contra-indicated against CHQ and HCHQ (Table 4)

TABLE 4: Drugs predicted to have adverse drug-drug episodes when co-administered with either Chloroquine orHydroxychloroquine

\begin{tabular}{ll}
\hline Drug & Indication \\
\hline Dextropropoxyphene & An analgesic drug used to relieve pain associated with cancer chemotherapy \\
Metamizole & An analgesic drug for treating mild to moderate pain of different origins \\
Amiodarone & An antiarrhythmic drug used to treat irregular heartbeat \\
Bepridil & An antiarrhythmic channel blocker used treat hypertension and chest pain \\
Flecainide & An antiarrhythmic drug used to abate serious irregular heartbeats \\
Rifampicin & An antimycobacterial indicated in the treatment of all forms of tuberculosis \\
Rifapentine & An analogue of rifampicin also used to treat tuberculosis \\
Carbamazepine & An anticonvulsant that decreases nerve impulses responsible for seizures and \\
& nerve pain \\
Phenobarbital & A barbiturate anticonvulsant used as a hypnotic \\
Primidine & An anticonvulsant drug used to treat tremor and other neurological conditions \\
St John's Wort & Used as an antidepressant in patients suffering from attention-deficit hyperactivity \\
& disorder. It could also be used to treat menopausal symptoms. Also applied topically for \\
Ziprasidone & wound healing \\
& Antipsychotic drug for schizophrenia and bipolar disorder \\
\hline
\end{tabular}

Analysis of the ongoing trials revealed different regimens for prophylaxis, for mild and asymptomatic patients, and for hospitalized patients with severe infection. The doses for each category of treatments should be streamlined to forestall the toxicity that could arise due to 
overdose. Incidentally, CHQ abuse is common in malaria-endemic countries of Africa [43]. Reports indicate that acute CHQ poisoning, both accidental and deliberate, could prove fatal. Since the COVID-19 outbreak in Nigeria, cases of poisoning arising from an overdose of CHQ had been reported. CHQ is well known, cheap and easily accessible in sub-Sahara Africa, but there are fears that repurposing CHQ for COVID-19 may lead to abuse, and could deprive patients requiring the drug for malaria treatment. The sharp increase in the cost of a pack of CHQ (containing $250 \mathrm{mg}$ CHQ and $155 \mathrm{mg}$ CHQ base) from $\$ 1.7$ to $\$ 9.75$ in Nigerian drug retail outlets lend credence to these reservations.

The host receptor for the coronavirus had been identified as angiotensin-converting enzyme 2 (ACE2) [44-45]. ACE2 converts angiotensin II to angiotensin 1-7. It is speculated that the binding of the virus to the ACE2 receptor increases the circulatory levels of angiotensin II, causing systemic inflammation and oxidative stress. Therefore, the effects of CHQ and HCHQ on the antioxidant:oxidant status of COVID-19 infected patients should be considered. Previous studies had reported CHQ-induced oxidative stress and genotoxicity in the liver of rodents [46-47]. It is plausible that the CHQ and HCHQ regimen being proposed as therapeutic interventions could exacerbate oxidative damage in susceptible organs such as the lungs, kidney, and liver.

Despite the spate of research and publications on COVID-19, researchers are uncertain whether the disease will ultimately cease or remain a deadly infectious disease. Whichever scenario that eventually pans out, the potential for COVID-19 infection in children could become a public health concern in Africa. During the MERS-COV and SARS-COV epidemics, few pediatric cases were observed. This trend, which has continued with COVID-19, gives a false impression that children are not susceptible to the infection. But, a current case series conducted in Shenzhen, China, showed that children presented with COVID-19 symptoms ranging from asymptomatic to mild [48]. Other 
studies suggested that the levels of expression of ACE2 receptors were not age-discriminatory, meaning that children could equally be at risk as adults [49-50]. The portent for Africa is that asymptomatic or mildly symptomatic children could escalate community transmission of the disease. Glucose-6-phosphate dehydrogenase deficiency (G6PDH) has been implicated as one of the causes of jaundice in children in sub-Saharan Africa. Unfortunately, CHQ and HCHQ are pro-oxidant drugs and their use in children with G6PDH could distort the redox status in red blood cells leading to hemolysis and other potentially fatal conditions. Invariably, policymakers must weigh the pros and cons of using CHQ and HCHQ as a therapeutic drugs for COVID-19 before endorsing their widespread use in Africa.

\section{Beyond CHQ and HCHQ repurposing: The African experience in managing COVID-19}

During the COVID-19 pandemic, the European Centre for Disease Prevention and Control (ECDC) published data from all continents of the world. The COVID-19 epidemiological profiles of the ten most populous countries in Africa were obtained from the ECDC on 10 April 2020. Analysis of the data showed that the two North African countries Egypt and Algeria contributed $27.4 \%$ of the total confirmed cases with a combined mortality of $22.1 \%$. Incidence in South Africa was $15.7 \%$, with a mortality rate of $0.93 \%$. The percentage infections and deaths in the East African countries (Ethiopia, Kenya, Tanzania, and Uganda) were $2.6 \%$ and $11.5 \%$, respectively. Nigeria had $2.4 \%$ of the total COVID-19 cases with a death rate of $2.4 \%$ (Table 5).

TABLE 5: Epidemiological data on COVID-19 in the ten most populous countries in Africa, 10 April 2020 


\begin{tabular}{|c|c|c|c|c|c|c|}
\hline $\mathrm{S} / \mathrm{N}$ & Country & Population & COVID-19 Cases & $\begin{array}{l}\text { Percentage of total } \\
\text { cases in Africa } \\
(\mathrm{n}=12280)\end{array}$ & $\begin{array}{l}\text { Number of } \\
\text { deaths }\end{array}$ & $\begin{array}{l}\text { Percentage } \\
\text { mortality }\end{array}$ \\
\hline 1 & Nigeria & $206,139,589$ & 288 & 2.35 & 7 & 2.43 \\
\hline 2 & Ethiopia & $114,963,588$ & 56 & 0.45 & 2 & 3.57 \\
\hline 3 & Egypt & $102,334,404$ & 1699 & 13.84 & 118 & 6.94 \\
\hline 4 & DR Congo & $89,561,403$ & 215 & 1.75 & 20 & 9.30 \\
\hline 5 & Tanzania & $59,734,218$ & 24 & 0.20 & 1 & 4.17 \\
\hline 6 & South Africa & $59,308,690$ & 1934 & 15.7 & 18 & 0.93 \\
\hline 7 & Kenya & $53,771,286$ & 184 & 1.50 & 7 & 3.80 \\
\hline 8 & Uganda & $45,741,007$ & 53 & 0.43 & 0 & 0 \\
\hline 9 & Algeria & $43,851,044$ & 1666 & 13.6 & 235 & 15.18 \\
\hline 10 & Sudan & $43,849,260$ & 14 & 0.11 & 2 & 14.29 \\
\hline
\end{tabular}


This trend agreed with a modeling study that grouped Algeria, Egypt and South Africa as high risk countries for the virus [51]. The prevalence of diabetes and HIV, in North Africa and South Africa, respectively, could have contributed to this trend [52]. As of 10 April 2020, South Africa had the highest incidence of COVID-19 infections in Africa, but the survival rates were also the highest. Could this be a case of underlying HIV conditions exacerbating the severity of COVID-19 infections in non-antiretroviral therapy compliant patients while the chances of survival were boosted in the antiretroviral compliant patients? A further food for thought was the scenario in East Africa. Infections were at a premium but mortality rates were high. Could there be any correlation with the high altitude in these countries? These posers have thrown up some paradoxical scenarios in Africa that warrant further investigations.

At the onset of the pandemic, only a few African countries had the capacity for the diagnostic testing of COVID-19 East Africa [53]. However, Nigeria's response had been commendable with a combination of strategies including public enlightenment campaigns, enforcement of lockdown, aggressive contact tracing and strict surveillance at points of entry, reprimand for recalcitrant citizens, among other measures. Positively, a news update monitored in Lagos, Nigeria, reported the development of a self e-screening toolkit by the African Centre of Excellence for the Genomics of Infectious Disease (ACEGID), domiciled in Redeemer's University, Nigeria in conjunction with an indigenous IT firm, Kreateng. The toolkit, written in the three major Nigerian languages, contained a series of questions to assess an individual's risk of COVID-19 using scientific and public health evidence. High-risk individuals, especially those with international travel histories or had been exposed to COVID-19 infected people, were referred to the Nigeria Centre for Disease Control for further tests [54].

\section{CONCLUSION}


The final aim of this literature review was to stimulate further research and trials on repurposing CHQ and HCHQ as anti-COVID drugs taking into consideration the peculiarities of Africans, especially those with underlying health conditions. The lack of clinical results on the safety and tolerability of CHQ and HCHQ signify that it is yet early times to make definite conclusions about their overall efficacy against COVID-19. Hopefully, the scientific community will see this pandemic as an opportunity to develop broad-spectrum vaccines against the coronaviruses and other pathogenic viruses.

\section{Data Availability}

All relevant data are embedded in the manuscript.

\section{Conflicts of Interest}

The author declares that there is no conflict of interest regarding the publication of this paper.

\section{Funding}

This research did not receive any funding from any organization.

\section{Acknowledgments}

The author appreciates the Faculty of Basic Medical Sciences, Redeemer's University, Ede, Nigeria for use of its facilities.

\section{References}

[1] Adhikari, S., Meng, S., Wu, Y. et al. Epidemiology, causes, clinical manifestation and diagnosis, prevention and control of coronavirus disease (COVID-19) during the early outbreak period: a scoping review. Infect Dis Poverty 2020; 9:29. 
[2] European Centre for Disease Prevention and Control Situation Update, $10 \quad$ April 2020. https://www.ecdc.europa.eu/en/geographical-distribution-2019-ncov-cases. Accessed 10 April 2020

[3] Mbonu NC, van den Borne B, De Vries NK..Stigma of People with HIV/AIDS in Sub-Saharan Africa: A Literature Review. Journal of Tropical Medicine 2009, 145891. https://doi.org/10.1155/2009/145891

[4] Zhou F, Yu T, Du R, Fan G, Liu Y, Liu Z, Xiang J, Wang Y, Song B, Gu X, Guan L, Wei Y, Li H, Wu X, Xu J, Tu S, Zhang Y, Chen H, Cao B. Clinical course and risk factors for mortality of adult inpatients with COVID-19 in Wuhan, China: a retrospective cohort study. The Lancet 2020; 395(10229):1054-1062.

[5] Wu Z, McGoogan JM. Characteristics of and Important Lessons From the Coronavirus Disease 2019 (COVID-19) Outbreak in China: Summary of a Report of 72314 Cases From the Chinese Center for Disease Control and Prevention. JAMA 2020 ; 24. doi:10.1001/jama.2020.264

[6] Zhu F, Cao Y, Xu S, Zhou M. Co-infection of SARS-CoV-2 and HIV in a patient in Wuhan city, China. J of Medical Virology 2020. https://onlinelibrary.wiley.com/doi/full/10.1002/jmv.25732

[7] Joob B, Wiwanitkit V. SARS-CoV-2 and HIV. J Med Virol 2020 .doi: 10.1002/jmv.25782

[8] Guo W, Weng HL, Bai H, Liu J, Wei XN , Zhou K, Sande A. Quick Community Survey on the Impact of COVID-19 Outbreak for the Healthcare of People Living With HIV. Zhonghua Liu Xing Bing Xue Za Zhi. 2020; 41(5):663-667. doi:10.3760/cma.j.cn11233820200314-00345

[9] Shalhoub S, AlZahrani A, Simhairi R, Mushtaq, A. Successful recovery of MERS CoV pneumonia in a patient with acquired immunodeficiency syndrome: A case report. Journal of Clinical Virology 2015; 62:69-71.

[10] Fox A, Horby P, Ha NH, Hoa LN, Lam NT, Simmons C, Farrar J, Kinh NV, Wertheim H Influenza A H5N1 and HIV coinfection: case report. BMC Infectious Diseases 2010; 10(1):167

[11] Smith T, Bushek J, Prosser T. COVID-19 Drug Therapy - Potential Options. https://www.elsevier.com/_data/assets/pdf_file/0007/988648/COVID-19-Drug-Therapy_Mar-2020.pdf. Assessed April 3 2020 
[12] Dong L, Hu S, Gao J. Discovering drugs to treat coronavirus disease 2019 (COVID-19). Drug Discoveries \& Therapeutics 2020; 14(1):58-60.

[13] Murray SM, Down CM, Boulware DR, Stauffer WM, Cavert WP, Schacker TW, Jason M. Brenchley JM, Douek DC. Reduction of immune activation with chloroquine therapy during chronic HIV infection. Journal of Virology 2010; 84; $12082-12086$.

[14] Flegg JA, Metcalf CJE, Gharbi M, Venkatesan M, Shewchuk T, Hopkins Sibley C, Guerin PJ. Trends in antimalarial drug use in Africa. Am J Trop Med Hyg 2013; 89(5):857-865. doi: 10.4269/ajtmh.13-0129.

[15] Ocan, M., Akena, D., Nsobya, S. et al. Persistence of chloroquine resistance alleles in malaria endemic countries: a systematic review of burden and risk factors. Malar J 2019 18: 76 https://doi.org/10.1186/s12936-019-2716-z

[16] Mallucci, L Effect of chloroquine on lysosomes and on growth of mouse hepatitus virus (MHV-3). Virology 1966; 8:355-362.

[17] Shimizu Y, Yamamoto S, Homma M, Ishida N. Effect of chloroquine on the growth of animal viruses. Archiv Fur Die Gesamte Virusforschung 1972; 36(1-2), 93-104. doi:10.1007/bf01250299.

[18] Ericsson CD, Robert Steffen R, Isaäcson M. Viral hemorrhagic fever hazards for travelers in Africa. Clinical Infectious Diseases 2001, 33(10), 1707-1712, https://doi.org/10.1086/322620

[19] Ferraris O, Moroso M, Pernet O, Emonet S, Paranhos-Baccalà G, Peyrefitte CN. Evaluation of Crimean-Congo hemorrhagic fever virus in vitro inhibition by chloroquine and chlorpromazine, two FDA approved molecules. Antiviral Research $2015 ; 118: 75-8$

[20] Allaranga Y, Kone ML, Formenty P, Yada A. Lessons learned during active epidemiological surveillance of Ebola and Marburg viral hemorrhagic fever epidemics in Africa. East African Journal of Public Health 2010; 7(1):30-36.

[21] Dowall SD, Bosworth A, Watson R, Bewley K, Taylor I, Rayner E, Hunter L, Pearson G, Easterbrook L, Pitman J, Hewson R, Carroll MW. Chloroquine inhibited Ebola virus replication in vitro but failed to protect against infection and disease in the in vivo guinea pig model. The Journal of general virology 2015; 96(12):3484-3492. https://doi.org/10.1099/jgv.0.000309

[22] Savarino, A, Gennero, L, Chen, HC, Serrano, D, Malavasi, F, Boelaert, JR, Sperber, K. Anti-HIV effects of chloroquine: mechanisms of inhibition and spectrum of activity. AIDS 2001; 15(17): 2221-2229. 
[23] Roques, P., Thiberville, S. D., Dupuis-Maguiraga, L., Lum, F. M., Labadie, K., Martinon, F., Gras, G., Lebon, P., Ng, L., de Lamballerie, X., Le Grand, R. Paradoxical effect of chloroquine treatment in enhancing Chikungunya virus infection. Viruses 2018; 10(5):268. https://doi.org/10.3390/v10050268

[24] Savarino A, Boelaert JR, Cassone A, Majori G, Cauda R. Effects of chloroquine on viral infections: an old drug against today's diseases? Lancet Infect Dis. 2003; 3(11):722-727.

[25] Keyaerts E, Li S, Vijgen L, Rysman E, Verbeeck J, Ranst MV, Maes P. Antiviral activity of Chloroquine against human coronavirus OC43 infection in newborn mice. Antimicrobial Agents and Chemotherapy 2009; 53 (8): 3416-3421. doi: 10.1128/AAC.01509-08

[26] Yao X, Ye F, Zhang M, Cui C, Huang B, Niu P, Liu X, Zhao L, Dong E, Song C, Zhan S, Lu R, Li H, Tan W, Liu D. In vitro antiviral activity and projection of optimized dosing design of hydroxychloroquine for the treatment of severe acute respiratory syndrome coronavirus 2 (SARS-CoV-2). Clin Infect Dis. 2020. pii: ciaa237. doi: 10.1093/cid/ciaa237.

[27] Falzarano D, Safronetz D, Prescott J, Marzi A, Feldmann F, Feldmann H. Lack of protection against ebola virus from chloroquine in mice and hamsters. Emerging Infectious Diseases 2015; 21(6), 1065-1067. https://doi.org/10.3201/eid2106.150176

[28] Gao J, Tian Z, Yang X. Breakthrough: Chloroquine phosphate has shown apparent efficacy in treatment of COVID-19 associated pneumonia in clinical studies. Biosci Trends 2020; 14(1):72-73. doi: 10.5582/bst.2020.01047.

[29] Gautret P, Lagier JC, Parola P, Hoang VT, Meddeb L, Mailhe M, Doudier B, Courjon J, Giordanengo V, Vieira VE, Dupont HT, Honoré S, Colson P, Chabrière E, La Scola B, Rolain JM, Brouqui P, Raoult D. Hydroxychloroquine and azithromycin as a treatment of COVID-19: results of an open-label non-randomized clinical trial. Int J Antimicrob Agents 2020 20:105949. doi: 10.1016/j.ijantimicag.2020.105949.

[30] Gupta SP. Inhibition of viruses promising targets and their importance. In: Studies on hepatitis viruses 2018 ; 35-65. doi:10.1016/b978-0-12-813330-9.00003-x

[31] Richman DD, Nathanson N. Antiviral Therapy. Viral Pathogenesis 2016; 271-287. doi:10.1016/b978-0-12-800964-2.00020-3 
[32] Soomro N, Fitzgerald G, Seeley J, Schatz E, Nachega JB, Negin J. Comparison of antiretroviral therapy adherence among HIVinfected older adults with younger adults in Africa: Systematic Review and Meta-analysis. AIDS and behavior 2019; 23(2), 445-458. https://doi.org/10.1007/s10461-018-2196-0

[33] Full genomic sequence of COVID-19 in Africa. https://www. github.com/acegid/CoV_Sequences. Accessed 7 April 2020

[34] Ruan YJ, Wei CL, Ee AL, Vega VB, Thoreau H, Su ST, Chia JM, Ng P, Chiu KP, Lim L, Zhang T, Peng CK, Lin EO, Lee NM, Yee SL, Ng LF, Chee RE, Stanton LW, Long PM, Liu ET. Comparative full-length genome sequence analysis of 14 SARS coronavirus isolates and common mutations associated with putative origins of infection. Lancet 2003, 361(9371):1779-85.

[35] Kopecky-Bromberg SA, Martínez-Sobrido L, Frieman M, Baric RA, Palese P. Severe acute respiratory syndrome coronavirus open reading frame (ORF) 3b, ORF 6, and nucleocapsid proteins function as interferon antagonists. Journal of virology 2007; 81(2), 548-557. https://doi.org/10.1128/JVI.01782-06.

[36] German Advisory Committee Blood (Arbeitskreis Blut), Subgroup 'Assessment of Pathogens Transmissible by Blood' Human Immunodeficiency Virus (HIV). Transfusion medicine and hemotherapy : offizielles Organ der Deutschen Gesellschaft fur Transfusionsmedizin und Immunhamatologie 2016; 43(3): 203-222. https://doi.org/10.1159/000445852

[37] Guangdi L, Clercq E. Therapeutic options for the 2019 novel coronavirus (2019-nCoV). Nature Reviews Drug Discovery 2020; 19: $149-150$.

[38] Schrezenmeier, E., Dörner, T. Mechanisms of action of hydroxychloroquine and chloroquine: implications for rheumatology. Nat Rev Rheumatol 2020; 16: 155-166. https://doi.org/10.1038/s41584-020-0372

[39] Savarino A, Lucia MB, Rastrelli E, et al. Anti-HIV effects of chloroquine: inhibition of viral particle glycosylation and synergism with protease inhibitors. J Acquir Immune Defic Syndr. 2004;35(3):223-232. doi:10.1097/00126334-200403010-00002

[40] Ferner RE, Aronson JK .Chloroquine and hydroxychloroquine in covid-19. Use of these drugs is premature and potentially harmful. BMJ 2020; 369.

[41] Swedish hospitals abandon trial of promising malaria drug chloroquine for coronavirus patients after it caused them blinding headaches, vision loss and agonising cramps. News release. Daily Mail. 8 April 2020. Accessed 8 April 2020. 
https://www.dailymail.co.uk/news/article-8199477/Swedish-hospitals-stop-prescribing-chloroquine-coronavirus-patients-adverseeffects.html

[42] Bonny A, Ngantcha M, Scholtz W, Chin A, Nel G, Anzouan-Kacou JB, Karaye KM, Damasceno A, Crawford TC. Cardiac Arrhythmias in Africa: Epidemiology, management challenges, and perspectives. J Am Coll Cardiol. 2019; 73(1):100-109. doi: 10.1016/j.jacc.2018.09.084.

[43] Ihenacho NC, Magulike E. Chloroquine abuse and heart block in Africans. Australian and New Zealand J of Medicine 1989; 19(1), 17-21. doi:10.1111/j.1445-5994.1989.tb01666.x

[44] Hoffmann M, Kleine-Weber H, Schroeder S, Kruger N, Herrler T, Erichsen S, Schiergens TS, Herrler G, Wu NH, Nitsche A, et al. SARS-CoV-2 cell entry depends on ACE 2 and TMPRSS 2 and is blocked by a clinically proven protease inhibitor. Cell 2020; 181:1-1

[45] Wan Y, Shang J, Graham R, Baric RS, Li F. Receptor recognition by novel coronavirus from Wuhan: an analysis based on decadelong structural studies of SARS. J Virol 2020; 94(7):e00127-20-e00127-20.

[46] Farombi, E.O. Genotoxicity of chloroquine in rat liver cells: Protective role of free radical scavengers. Cell Biol Toxicol 22, 159167 (2006). https://doi.org/10.1007/s10565-006-0173-2

[47] Kumar MS, Singh P, Rath SK. Protective effect of quercetin on chloroquine-induced oxidative stress and hepatotoxicity in mice. Malar Res Treat. 2013;2013:141734. doi: 10.1155/2013/141734

[48] Wang XF, Yuan J, Zheng YJ, et al. Clinical and epidemiological characteristics of 34 children with 2019 novel coronavirus infection in Shenzhen. Zhonghua Er Ke Za Zhi. 2020; 58:E008

[49] Zimmermann P, Nigel C. Coronavirus infections in children including COVID-19. An Overview of the epidemiology, clinical features, diagnosis, Treatment and prevention options in children. The Pediatric Infectious Disease Journal $2020 . \quad$ doi: 10.1097/INF.0000000000002660.

[50] Xie Z. Pay attention to SARS-CoV-2 infection in children. Pediatric Intervention 2020; 4(1): https://doi.org/10.1002/ped4.12178

[51] Pullano, GM G Pinotti G et al. Preparedness and vulnerability of African countries against importations of COVID-19: a modelling study. Lancet. 2020395 (10227), P871-877, https://doi.org/10.1016/S0140-6736 (20)30411-6 
[52] Assaad Khalil SH, Abdelaziz SI, Al Shammary A, Al Zahrani A, Amir A, Elkafrawy N, Hassoun AA, Hostalek U, Jahed A, Jarrah N, Mrabeti S, Paruk I, Zilov AV. Prediabetes management in the Middle East, Africa and Russia: Current status and call for action. Diab Vasc Dis Res. 2019 ; 16(3):213-226. doi: 10.1177/1479164118819665.

[53] Nkengasong JN and Mankoul W. Looming threat of COVID-19 infection in Africa: act collectively, and fast. The Lancet 2020;395( I10227), P841-84

[54] Self e-screening toolkit for COVID-19. (kreateng.org/covid-19/start). Accessed 9 April 2020 